\title{
360-Degree Performance Appraisal and Feedback System: A Study with Heads of Departments in Çanakkale Onsekiz Mart University
}

\author{
360 Derece Performans Değerlendirme ve Geri Bildirim Sistemi: \\ Çanakkale Onsekiz Mart Üniversitesi Daire Başkanları Üzerine Bir \\ Uygulama \\ Mustafa GÖRÜN* \\ İsmail KAYAR** \\ Burak VAROL ${ }^{* * *}$
}

\begin{abstract}
Performance appraisal system is one of the most important determinants for the achievement of goals for human resources management. For that reason, the way and the methods used by organizations to evaluate the performance of their employees are critical for them in reaching their goals. Thus, it is necessary to accurately evaluate the performance of the employees in the organization and then to improve particularly the weaknesses of the employees in line with the goals of the organization. Traditional performance evaluation systems, where a single supervisor evaluates the performance of all employees, may not always necessarily lead to an objective and effective evaluation. Therefore, taking a backseat after the 1980s, traditional performance evaluations systems have been replaced by the 360-degree performance appraisal system, which is used for the purposes of uncovering the potential of the employees in an organization, informing the employees of their weaknesses through feedbacks and compensating for their weaknesses for the achievement of goals. The 360-degree performance appraisal system highly focuses on the data, which are obtained from multiple sources and provide feedbacks to employees. The data collected from multiple sources enhance the objectivity and effectiveness of the resulting evaluation. Also, the feedbacks allow employees to see their weaknesses from the perspective of others and increase their job motivation. The present study theoretically analyzes the 360-degree performance appraisal system, which is a prominent system in human resources management, presents an empirical survey with the heads of departments in Çanakkale Onsekiz Mart University and seeks to outline their weaknesses and strengths.
\end{abstract}

Keywords: Performance, 360 Degree Performance Appraisal, Feedback

$\ddot{O} z$

Performans değerlendirme sistemi insan kaynakları yönetiminin hedefe ulaşmada en önemli belirleyicilerinden biridir. $\mathrm{Bu}$ nedenle örgütlerin hedeflerine ulaşabilmelerinde çalışanların performanslarını nasıl ve hangi yöntem ile belirledikleri büyük önem taşımaktadır. Dolayısıyla örgüt çalışanlarının performanslarının doğru bir yöntemle değerlendirilmesi ve sonucunda çalışanların özellikle eksik yönlerinin kurumun hedeflerine uygun olarak geliştirilmesi gerekmektedir. Geleneksel performans değerlendirme sistemlerinde çalışanların performanslarının tek bir kişi tarafından değerlendirilmesi her zaman objektif ve etkin bir değerlendirme sonucu ortaya çıaramama riskini içinde barındırmaktadır. Bu nedenle 1980'lerden itibaren geleneksel performans değerlendirme sistemlerinin yerini 360 derece performans değerlendirme sistemi almış; örgüt çalışanlarının sahip oldukları potansiyelin ortaya çıkarılması, çalışanların eksik yönlerinin geri bildirim yoluyla kendilerine iletilmesi ve yeniden hedefe ulaşmada eksik yönlerin giderilmesini sağlamak amacıyla kullanılmaya başlanmıştır. 360 derece performans değerlendirme sisteminde veriler pek çok kaynaktan alındığı ve çalışana geribildirim sağladığı için yoğun bir şekilde kullanılmaktadır. Verilerin birden fazla kaynaktan alınması değerlendirmenin objektifliğinin ve etkinliğinin artmasını sağlamaktadır. Çalışana geri bildirim yapılması ise bir yandan çalışanın zayıf yönlerini başkalarının gözünden görmesini diğer yandan da işteki motivasyonunun artmasını sağlamaktadır. Bu çalışmada insan kaynakları yönetiminin önemli konularından biri olan 360 derece performans değerlendirme sistemi teorik olarak incelenmiş, Çanakkale Onsekiz Mart Üniversitesi'nde çalışan daire başkanları üzerinde ampirik bir araştırma yapılmış ve daire başkanlarının güçlü ve zayıf yönleri genel hatları itibariyle ortaya konulmaya çalışılmıştır.

Anahtar Kelimeler: Performans, 360 Derece Performans Değerlendirmesi, Geri Bildirim

\footnotetext{
* Prof. Dr., Çanakkale Onsekiz Mart University, Faculty of Political Sciences, Department of Political Science and Public Administration,mgorun@comu.edu.tr

${ }^{* * *}$ Res. Asst., Çanakkale Onsekiz Mart University, Faculty of Political Sciences, Department of Political Science and Public Administration, ismailkayar@comu.edu.tr

**** Master's Degree Student, Çanakkale Onsekiz Mart University, Institute of Social Sciences, Department of Public Administration, burakvarol@stu.comu.edu.tr
}

Görün, M., Kayar İ., Varol B., (2018). 360-Degree Performance Appraisal and Feedback System: A Study with Heads of Departments in Çanakkale Onsekiz Mart University, Gaziantep University Journal of Social Sciences, 17 (4), 1425-1437, Submission Date: 30-07-2018, Acceptance Date: 27-09-2018.

Araştırma Makalesi. 


\section{Introduction}

Human resources are the elements that operate to enable organizations to reach the specified goals. Organizations can reach their goals through human resources, that is, through employees. Therefore, the most important and indispensable element of management is human resources, i.e., employees (Eryılmaz, 2015, p. 309). Today, it is commonly held that employees are one of the most critical elements in an institution. Since well-trained and motivated employees make it possible for institutions to achieve their goals and to perform a sustainable competition (Dinç, 2005, p. 1). So that employees are well-trained, it is essential to determine their areas of development. Employees, provided with training to improve their weaknesses, would both better themselves and be more motivated to strive to achieve the goals of the institution. Given the critical importance of the performance of employees for institutions, performance appraisals should be prudently and objectively carried out. In this sense, one of the most remarkable and widely used systems is 360-degree performance appraisal.

360-degree performance appraisal entails an evaluation made by those who come in contact with the employee being assessed during working hours and have the opportunity to directly observe his or her performance. The appraisal seeks to obtain the views of several employees at senior, peer and junior levels, instead of the views of only senior-level employees (Mabey, 2001, p. 41). Further, it includes a self-evaluation based on certain criteria, compares the whole data and determines the weaknesses and strengths of the employee being assessed.

The present study discusses 360-degree performance appraisal, which has been given more prominence than traditional performance appraisal methods and more widely used today, within the conceptual framework. Within this framework, the study first addresses performance appraisal, the necessity and benefits of performance appraisal, 360-degree performance appraisal and feedback, and the advantages of 360-degree performance appraisal system. Then, it analyses the performances of the head of departments in Çanakkale Onsekiz Mart University based on the 360-degree performance appraisal system and provides a general outline and discussion of the data obtained under the headings of findings.

\section{Conceptual Framework}

\section{Performance Evaluation}

Performance indicates the total measure of qualitative and quantitative contributions to the objectives of an organization made by one or several employees of the organization (Güngör and Biberci, 2011, p. 2) and also refers to the extent that the employee fulfills the task given to him or her within a certain period of time (Arslan et al., 2016, p. 79). Performance appraisal is the process of evaluation of employee performance through the comparison and measurement of performance based on pre-defined standards (Akdoğan and Demirtaş, 2009, p. 51). The results of the appraisal are communicated to employees, thus, they have the opportunity to learn about their own performance (Palmer, 1993, p. 9). Providing feedback on the success and insufficiencies of an employee at work, performance appraisal underlies various HR practices such as recruitment, promotion, rewarding and dismissal (Kara, 2010, p. 88).

Performance appraisal is a tool used for evaluating the current performance of employees, supporting the employees and providing them with an opportunity to see how well they are performing to achieve the objectives and to do the necessary (Pocket Mentor, 2009, p. 12).

For the purpose of attaining their objectives, it is of prime importance for organizations to measure the individual performances of their employees in order to understand the current situation and to facilitate the process of achieving the targeted success (Levine, 2010, p. 41). Performance appraisal, required to measure employee effectiveness, traditionally consists of 
one-dimensional evaluation; yet, taking a backseat after the 1980s, one-dimensional evaluation has been gradually replaced by new methods allowing for multiple participation and multifaceted evaluation.

\section{Necessity and Benefits of Performance Appraisal}

Policy implementers state, in relation to human resources, that performance appraisal is one of the most controversial issues in human resources management. However, the discussion mainly focuses on how and when to make performance appraisal. Therefore, there has been no discussion as to whether such appraisal is necessary or not (Palmer, 1993, p. 7). Since performance appraisal is essential to understand the objectives and practices of an organization and to determine the extent to which employees comply with these objectives.

Performance appraisal is a vital process for organizations to reach their goals. Performance appraisal is an individual psychological need for employees as well as a motivational need for an organization (Akdoğan and Demirtaş, 2009, p. 52).

It is reported that performance appraisal is a must for an organization committed to success for the following reasons (Pocket Mentor, 2009, p. 13):

- Provides subordinates with an understanding of the objectives, allowing them to reach the objectives as well,

- Gives employees timely feedbacks, which can increase productivity,

- Helps employees in their decisions on the pay, professional development and promotion opportunities,

- Defends the organization against legal actions taken by employees.

The benefits of performance appraisal, such as increasing managerial control on tasks and results, identifying the problems early and taking necessary precautions, synchronizing the objectives of employees to those of the organization, enhancing the common sense of ownership by increasing employee motivation, improving communication, promoting remedial or disciplinary actions, offering objective criteria, render PA essential for the organizations aiming for success (Barutçugil, 2002, p.127-128).

Gillen (1997, p. 8) discussed the benefits of PA under the headings of organization, appraiser and appraisee. Accordingly, more information on organizational performance, better communication, better motivation, higher organizational performance and more advanced data on planning are the benefits of the organization; better staff performance, eliminated problems and ready-made reports are the benefits of the appraiser; higher performance thanks to the identification of weaknesses, opportunities to discuss complaints and problems, a focused look on needs are the benefits of the appraisee.

Nowadays, it is highly important to evaluate the performance of employees in an objective way and to draw their developmental maps through feedbacks for the achievement goals of organizations; for, the performance of employees is a factor that directly affects the success of an organization. The increase in the number of employees in organizations and developments in the areas of information and expertise, particularly in the recent years, have entailed performance appraisal. In that regard, it seems infeasible to carry out a conventional method of performance appraisal, where a single supervisor evaluates the performances of all employees, in terms of knowledge, time and objectivity (Oruç et al., 2008, p. 5). Evaluations made by superiors are the most traditional way of performance evaluation (United States Office of Personnel Management, 1997, p. 2), and in this way, since employees are evaluated only by their superiors, the value judgments and abilities of these superiors may harm the objectivity of the appraisal (Oruç et al., 2008, p. 6). Today, the process of performance is considered as a 
whole and conducted from different perspectives, rather than including an evaluation of employees made only by superiors from a single point of view (Kubat, 2012, p. 53).

Foremost among the methods of multifaceted evaluation on the employees of an organization, which is performed by several people, not only by superiors, is 360-degree performance appraisal and feedback method.

\section{0-Degree Performance Appraisal and Feedback}

The concept of 360-degree performance appraisal system dates back to after the 1980s. However, it was not much preferred due to the structural and cultural characteristics of the period (Bağraçık, 2009, p. 51). It gained momentum in the 1990s, when large companies in the USA and western European countries widely used the system. Today, it is considered by managers and employees as an effective method in improving employee performance. As the system includes feedback, which is received from multiple sources, it is perceived as a more objective system; and, the idea that it is a more integrated and effective system, compared to the system evaluating performance based on the views of a single supervisor, has become more and more common (Barutçugil, 2002, p. 203).

As a concept, 360-degree performance appraisal supports the developmental feedback known as a multi-source feedback, multi-rater assessment, full-circle appraisal and peer evaluation, and measures compliance and behavior rather than personality (Rodgers and Manifold, 2002, p. 1301). This performance appraisal system utilizes the data provided by superiors, subordinates as well as clients or contractors of an employee (Alexandrua and Diana, 2015 , p. 318). Becoming a must for organizations due to increased number of employees in organizations, this system is the most recent and popular appraisal system built on multiple sources and feedbacks (Uygur and Sarıül, 2015, p. 192). It can be defined as an evaluation process where the performance of an employee is assessed based on the specific information on job performance obtained from the employee's colleagues, supervisors, those directly reporting the employee as well as the employee's internal and external customers (Arslan et al., 2016, p. 80).

Cheung (1999, p. 111) describes a 360-degree performance evaluation as a strategical tool for reviewing the health of organizational performance, helping service planning and objectives setting, and as a transition step to objective and subjective feedbacks, customerfocused organization and total quality management. The person being evaluated through this method is being assessed by everyone interacting with him or her at work (Bağrıçıı, 2009, p. 51), which allows a multi-source and more comprehensive evaluation instead of an evaluation based upon single-source information that are not very reliable.

360-degree performance appraisal is a method seeking to overcome the disadvantages of traditional assessment methods, or being alternative to such methods. Accordingly, it aims to assess employees from the perspectives of not only their superiors, but also their peers, internal and external shareholders and the employees themselves (Göksel, 2013, p. 68). The data collected from multiple sources in 360-degree performance appraisal indicate the extensive and impartial analysis of employee performance (Karkoulian et al., 2016, p. 1862).

The feedbacks incorporated in 360-degree performance appraisal are, perhaps, the most important reason that this appraisal is highly preferred today. A feedback is a set of data on how employees are perceived, seen and judged by others (Kaymaz, 2007, p. 143). This set of data is obtained through performance appraisal, and thus the weaknesses and strengths of an employee are determined by multiple sources. Following that, it is important to share these data with the employee and turn his or her weaknesses into strengths. Feedbacks create awareness and motivate employees to change behaviors (Brett and Atwater, 2001, p. 930). 360-degree 
performance appraisal is of capital importance also in the way that it makes possible to compare the self-evaluation of the employee, who is evaluated by himself or herself and by others in line with certain criteria, with the evaluations made by others (Garavan, T. N. et al, 1997, p. 135).

\section{Advantages of 360-Degree Performance Appraisal}

360-degree performance appraisal is now one of the most popular methods for evaluation due to the key advantages associated with it, which allow the organization to reach its goals and to motivate its employees. These advantages can be described as follows: enabling employees to know about the opinions of others on their performance, thus, to identify their weaknesses and strengths, clarifying the expectations from employees, providing more clear and fair feedbacks compared to traditional methods, and strengthening communication between employees and managers (Barutçugil, 2002, p. 203-204). In addition to these, the advantages of 360-degree performance appraisal can be shown on a table from the point of clients, superiors, employees, senior management, teams and organizations as follows:

Table 1: Advantages of 360-degree performance appraisal

\begin{tabular}{|c|c|}
\hline $\begin{array}{l}\text { Clients } \\
\text { - } \text { Input to services } \\
\text { - Having a say in service process } \\
\text { Participating in decisions on products and } \\
\text { services } \\
\text { - Availability of quality control processes } \\
\text { Respect for quality and opportunity to reward } \\
\text { quality } \\
\text { Contribution to new ideas }\end{array}$ & $\begin{array}{l}\text { Superiors } \\
\text { - Opportunity to see their personal supervision } \\
\text { skills } \\
\text { - } \quad \text { High-quality information on selection decisions } \\
\text { - Transforming their role from a performance judge } \\
\text { towards a performance coach } \\
\text { - Reliable information on any poor performance } \\
\text { they face up to } \\
\text { - Reliable information on behaviors }\end{array}$ \\
\hline $\begin{array}{l}\text { Employees } \\
\text { - Having a say in decision processes mostly } \\
\text { affecting each of them } \\
\text { - Opportunity to shape their career development } \\
\text { - Being more influential on the decisions at all } \\
\text { levels } \\
\text { - Having a say in leadership quality control } \\
\text { - Respect for quality and opportunity to reward }\end{array}$ & $\begin{array}{l}\text { agement } \\
\text { mity to see how they are judged by others } \\
\text { ality information on selection decisions } \\
\text { rming their role from a performance judge } \\
\text { a performance coach } \\
\text { gs for work groups or units and their } \\
\text { mental needs } \\
\text { of directly given reports for evaluation }\end{array}$ \\
\hline $\begin{array}{l}\text { Teams } \\
\text { - Opportunity to see how teams are serving } \\
\text { consumers } \\
\text { High-quality information on the selection of team } \\
\text { members } \\
\text { Opportunity to assess the developmental needs of } \\
\text { the team } \\
\text { - Reliable information on team leadership } \\
\text { Information on team performance }\end{array}$ & $\begin{array}{l}\text { Organization } \\
\text { - Better knowledge of HR decisions } \\
\text { - } \quad \text { Enhancing quality control and the relevance of } \\
\text { promotion } \\
\text { - Increased work motivation } \\
\text { - Opportunity to establish a link with performance } \\
\text { and rewards Opportunity to organize vision, } \\
\text { appraisal and competencies together }\end{array}$ \\
\hline
\end{tabular}

Source: Keçecioğlu, 2003, p. 15-16; aktaran Dinç, 2005: p. 104.

\section{An Application of the 360-Degree Performance Appraisal System: Example of Heads of Departments in Çanakkale Onsekiz Mart University}

\section{Research Purpose and Significance}

The purpose of this study is to promote the use of 360-degree performance appraisal, which is more effective, reliable and objective than conventional performance evaluation systems, in public institutions, to implement this performance appraisal in a selected public institution and to show its results. Given the rising importance of multi-source appraisals relative to the performance evaluation systems, characterized by an evaluation of subordinates by superiors, 360-degree performance appraisal need to be utilized by a greater number of public institutions. In this sense, this study seeks to implement a multi-source evaluation in a public institution and to reveal the resulting outcomes. 


\section{Research Method and Reliability}

The study employed quantitative research methods. The scale in this study was obtained from the study titled "The $360^{\circ}$ Performance Evaluation Tool" by Haigh (2016) and revised. The survey was administered to the subordinates in the departments at Çanakkale Onsekiz Mart University, to every head of department, to the superiors of the heads of departments, and to those who benefit from the services in some departments. The data obtained from a total of 145 survey forms were entered into IBM SPSS Statistics 24 program.

Following that, the study performed a factor analysis, and grouped the questions of similar nature in 4 different dimensions. These dimensions are as follows: "Having a Vision", "Personal Characteristics and Prestige", "Being Quality-oriented", "Approachability and Communication."

Table 2: Kaiser-Meyer-Olkin and Bartlett's test results

\begin{tabular}{|l|l|l|}
\hline \multicolumn{2}{|l|}{ KMO and Bartlett's Test } &, 939 \\
\hline Kaiser-Meyer-Olkin Measure of Sampling Adequacy. & 2916,217 \\
\hline \multirow{2}{*}{ Bartlett's Test of Sphericity } & Approx. Chi-Square & 325 \\
\cline { 2 - 3 } & df &, 000 \\
\cline { 2 - 3 } & Sig. & \\
\hline
\end{tabular}

Table 2 points that the result of KMO test, which is a measure of sampling adequacy, is 0,939. A value of KMO larger than 0,8 indicates that the variables for the factor analysis are perfectly suitable (Durmuş et al., 2016, p. 80). Further, the $\rho$ value in Bartlett test is remarkably lower than 0,05, which implies that the correlation between the variables is sufficient to perform the factor analysis (Durmuş et al., 2016, p. 79).

Table 3: Total variance explained output

\begin{tabular}{|c|c|c|c|c|c|c|c|c|c|}
\hline \multicolumn{10}{|c|}{ Total Variance Explained } \\
\hline \multirow[b]{2}{*}{ Comp. } & \multicolumn{3}{|c|}{ Initial Eigenvalues } & \multicolumn{3}{|c|}{$\begin{array}{l}\text { Extraction Sums of } \text { Squared } \\
\text { Loadings }\end{array}$} & \multicolumn{3}{|c|}{$\begin{array}{l}\text { Rotation Sums of } \text { Squared } \\
\text { Loadings }\end{array}$} \\
\hline & Total & $\begin{array}{l}\% \text { of } \\
\text { Variance }\end{array}$ & $\begin{array}{l}\text { Cum. } \\
\%\end{array}$ & Total & $\begin{array}{l}\% \text { of } \\
\text { Variance }\end{array}$ & $\begin{array}{l}\text { Cumulative } \\
\%\end{array}$ & Total & $\begin{array}{l}\% \text { of } \\
\text { Variance }\end{array}$ & $\begin{array}{l}\text { Cumulative } \\
\%\end{array}$ \\
\hline 1 & 15,001 & 57,697 & 57,697 & 15,001 & 57,697 & 57,697 & 5,529 & 21,267 & 21,267 \\
\hline 2 & 1,722 & 6,623 & 64,320 & 1,722 & 6,623 & 64,320 & 5,497 & 21,143 & 42,410 \\
\hline 3 & 1,417 & 5,452 & 69,772 & 1,417 & 5,452 & 69,772 & 5,336 & 20,524 & 62,934 \\
\hline 4 & 1,252 & 4,816 & 74,589 & 1,252 & 4,816 & 74,589 & 3,030 & 11,655 & 74,589 \\
\hline 5 & ,704 & 2,710 & 77,298 & & & & & & \\
\hline 6 &, 629 & 2,419 & 79,717 & & & & & & \\
\hline 7 &, 585 & 2,249 & 81,966 & & & & & & \\
\hline 8 & ,568 & 2,185 & 84,151 & & & & & & \\
\hline 9 & ,460 & 1,770 & 85,922 & & & & & & \\
\hline 10 &, 429 & 1,650 & 87,572 & & & & & & \\
\hline 11 & ,423 & 1,626 & 89,198 & & & & & & \\
\hline 12 & 370 & 1,424 & 90,622 & & & & & & \\
\hline 13 & ,309 & 1,188 & 91,810 & & & & & & \\
\hline 14 & ,297 & 1,142 & 92,953 & & & & & & \\
\hline 15 & ,261 & 1,005 & 93,958 & & & & & & \\
\hline 16 &, 225 &, 864 & 94,822 & & & & & & \\
\hline 17 & , 199 & ,767 & 95,588 & & & & & & \\
\hline 18 & , 191 &, 735 & 96,323 & & & & & & \\
\hline 19 &, 165 &, 636 & 96,959 & & & & & & \\
\hline 20 & 159 &, 611 & 97,570 & & & & & & \\
\hline 21 &, 138 &, 530 & 98,100 & & & & & & \\
\hline
\end{tabular}




\begin{tabular}{|l|l|l|l|l|l|l|l|l|l|}
\hline 22 &, 131 &, 503 & 98,604 & & & & & & \\
\hline 23 &, 114 &, 439 & 99,043 & & & & & & \\
\hline 24 &, 099 &, 382 & 99,425 & & & & & & \\
\hline 25 &, 079 &, 303 & 99,728 & & & & & & \\
\hline 26 &, 071 &, 272 & 100,000 & & & & & & \\
\hline
\end{tabular}

Table 4: Reliability analysis results

\begin{tabular}{|l|l|l|}
\hline Factor Name & Cronbach's Alpha & N of Items \\
\hline Personal Characteristics and Prestige & 0,942 & 7 \\
\hline Having a Vision & 0,937 & 7 \\
\hline Being Quality-oriented & 0,923 & 8 \\
\hline Approachability and Communication & 0,876 & 4 \\
\hline
\end{tabular}

Table 4 demonstrates that the Cronbach's Alpha value of each dimension is higher than 0,7 , which means that all dimensions are reliable.

\section{Findings}

In this study, the participants were asked to assign a value on a scale from 1 to 5 to each appraisee through the survey questions. The average score for all the questions in the dimensions, formed following the factor analysis, was calculated and recorded for each department. The appraisee was scored by his/her superior, subordinates, himself/herself and those who benefit from the services in some departments, on four different dimensions.

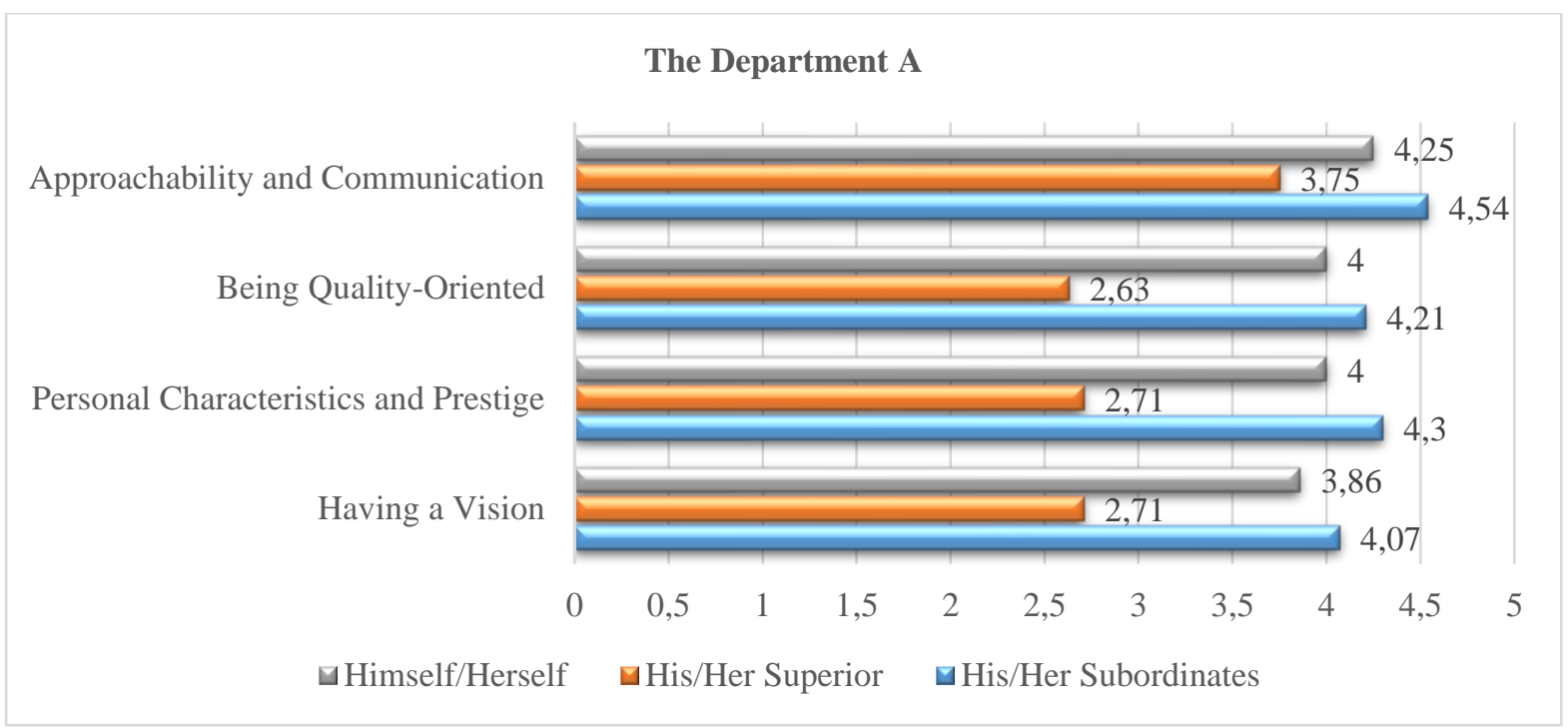

Figure 1: 360-degree performance appraisal for the department a

Figure 1 shows that the Head of Department A received low scores for each of these 4 dimensions from his/her superior. However, the scores he/she received from himself/herself and his/her subordinates were similar and higher than those given by his/her superior. Besides, the Head of Department A received the highest score on the dimension of "Approachability and Communication." 


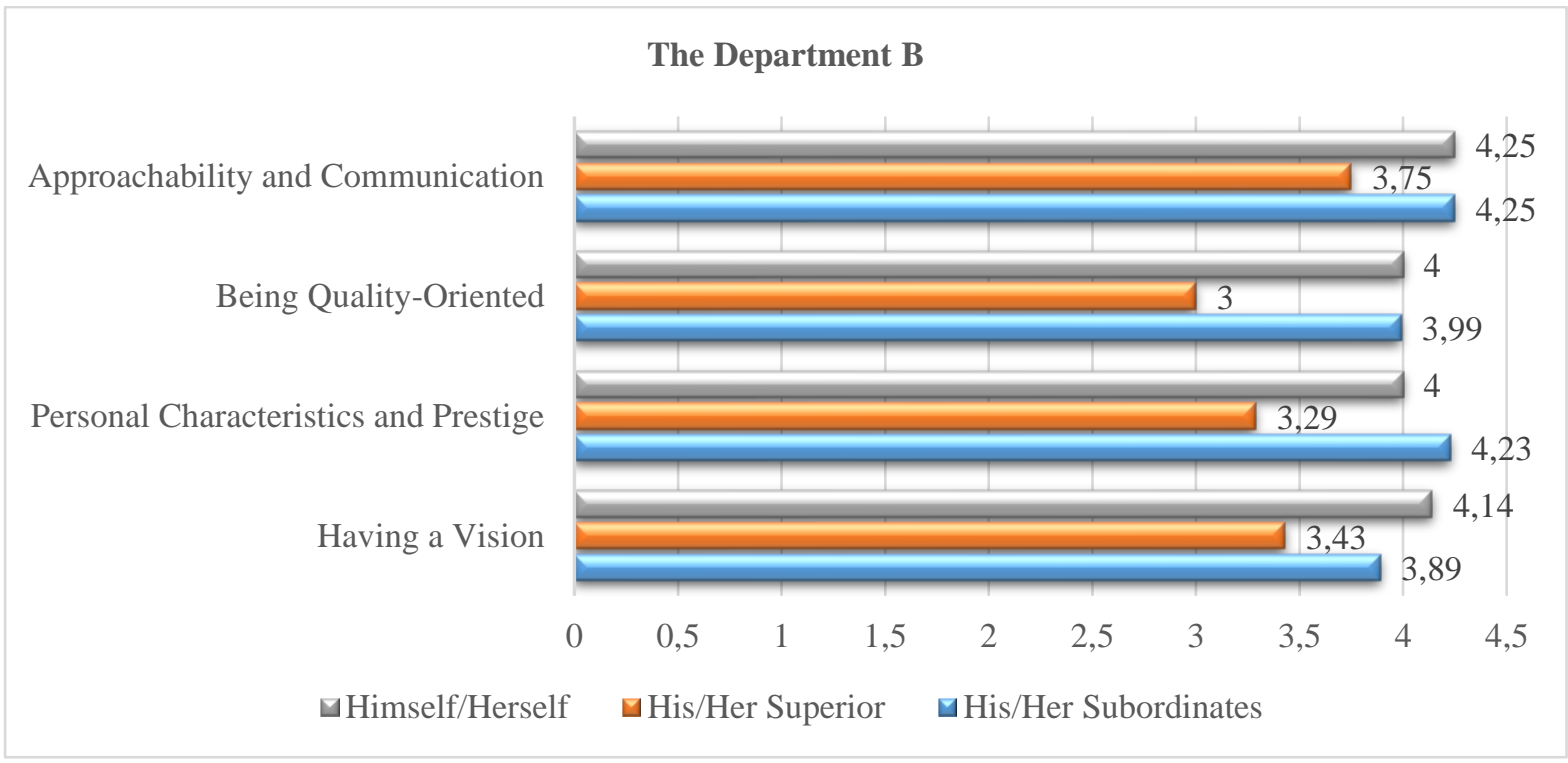

Figure 2: 360-degree performance appraisal for the department $b$

Figure 2 indicates that the highest score received by the Head of Department B was given by his/her subordinates in general. Further, the scores given by himself/herself were parallel to those given by his/her subordinates. The lowest score received by the Head of Department B was given by his/her superior. His/her lowest score was on the dimension of "Being Quality-oriented" while his/her highest score was on the dimension of "Approachability and Communication."

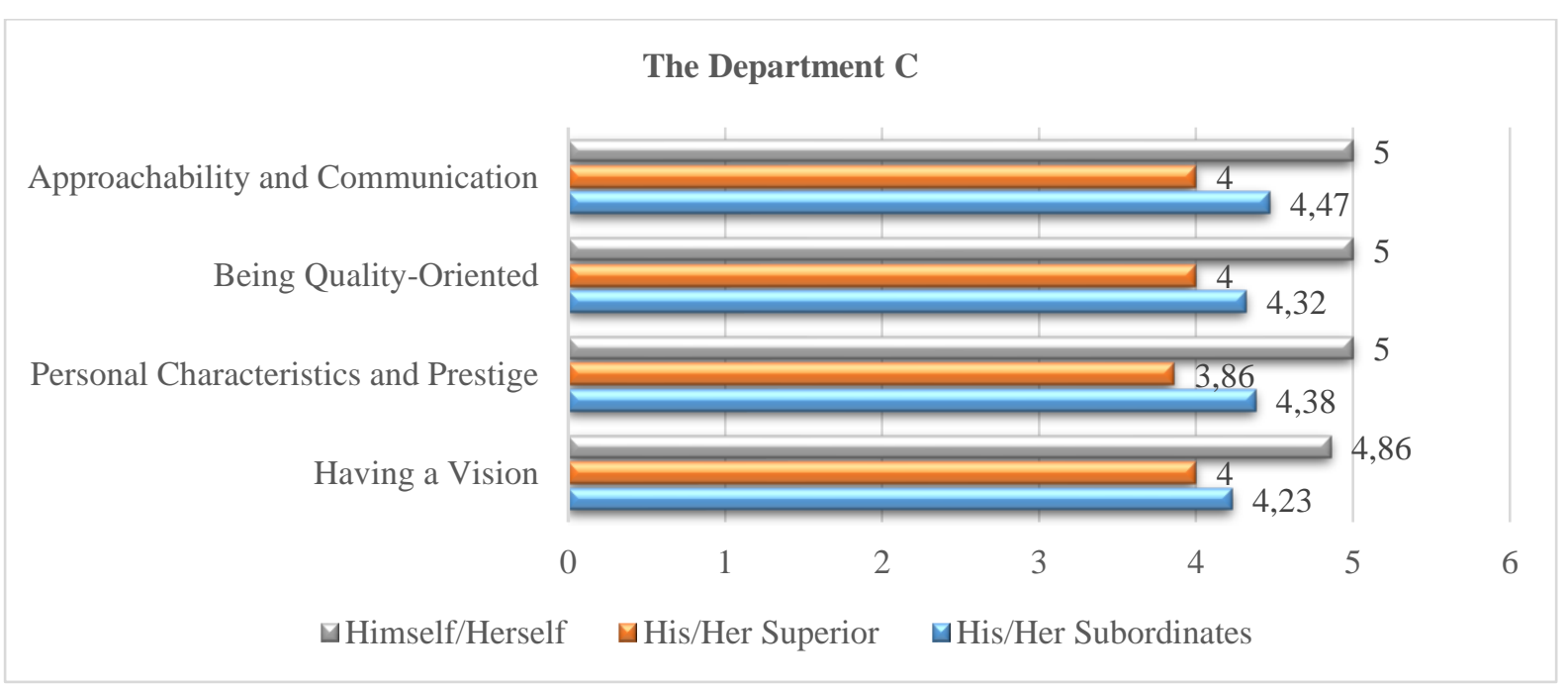

Figure 3: 360-degree performance appraisal for the department c

Figure 3 implies that there is a serious discrepancy between the scores given by the Head of Department $\mathrm{C}$ to himself/herself and the scores given by his/her superior. His/her lowest score was given by his/her superior whereas his/her highest score was given by himself/herself. In general, he/she received the highest score on the dimension on "Approachability and Communication." 


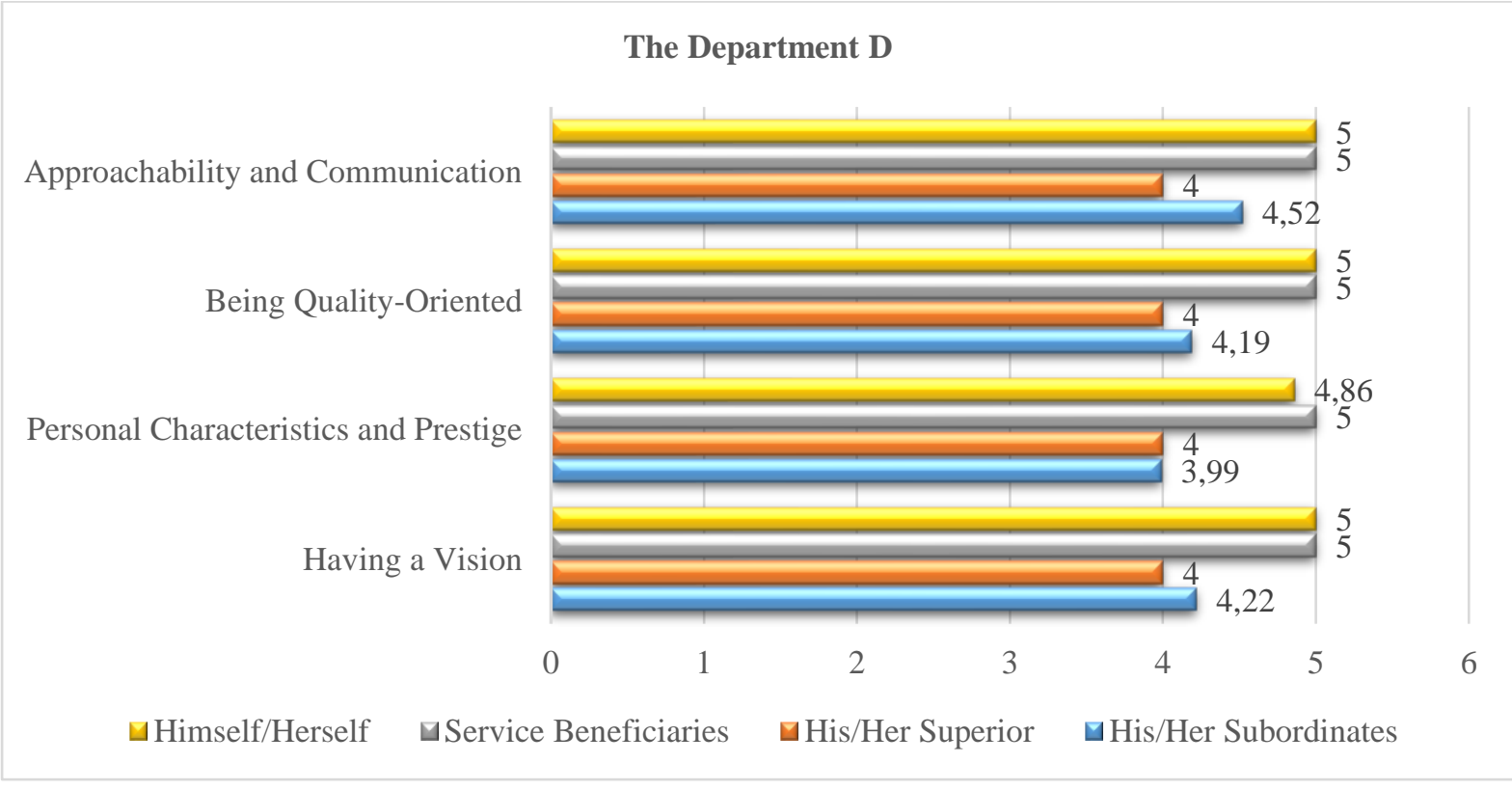

Figure 4: 360-degree performance appraisal for the department $d$

Figure 4 demonstrates that the scores given to the Head of Department D by himself/herself were parallel to the scores given by those who benefit from the services. Further, although the scores given by his/her superior and subordinates were lower, these scores were parallel to each other as well. The scores given to the Head of Department D on all these 4 dimensions were similar in general.

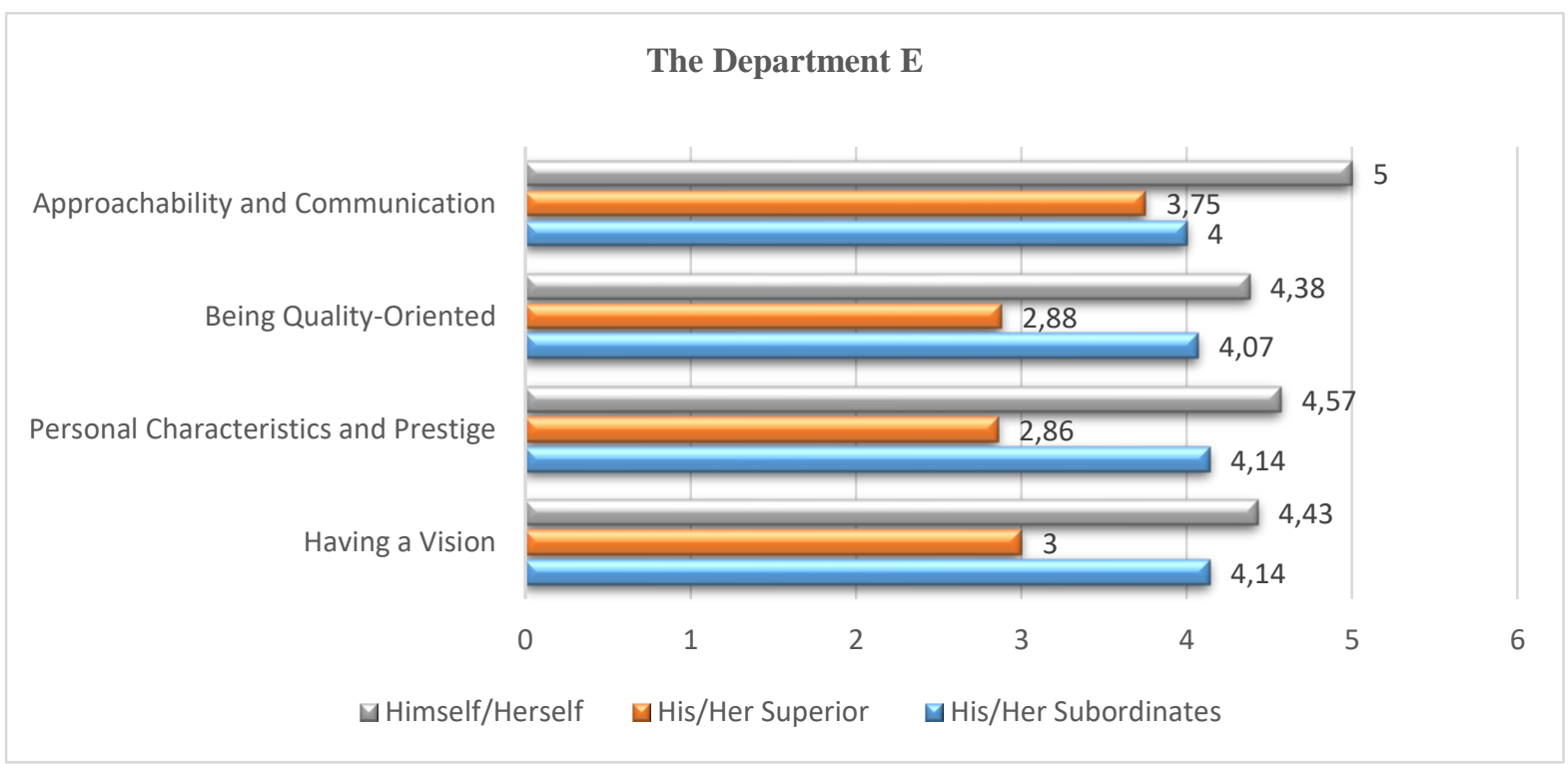

Figure 5: 360-degree performance appraisal for the head of department e

Figure 5 shows that the lowest scores given to the Head of Department $\mathrm{E}$ for each factor were given by his/her superior. He/she received the highest score from himself/herself. Moreover, there was a severe difference between all the scores. In general, he/she received the highest score on the dimension on "Approachability and Communication." 


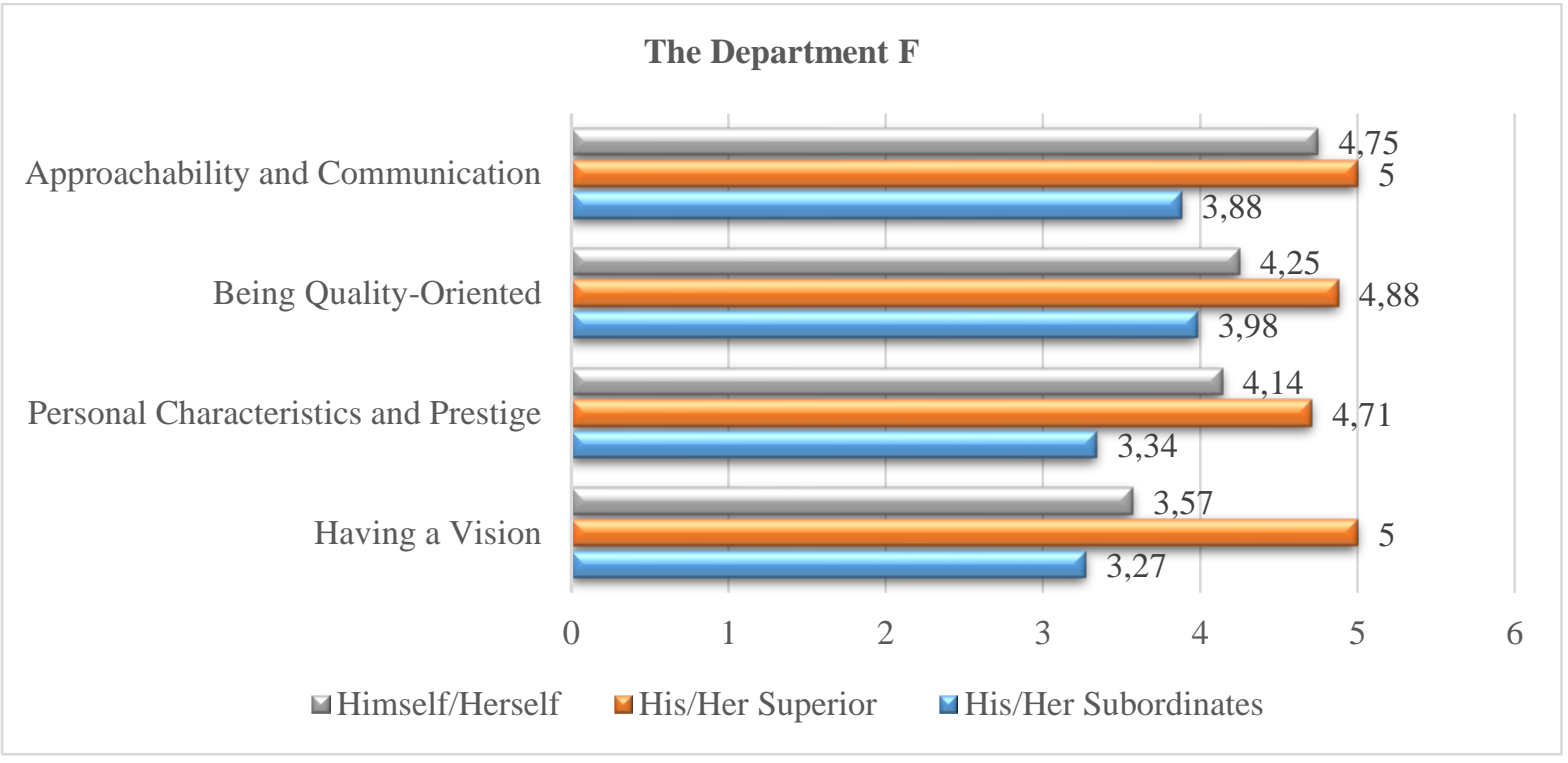

Figure 6: 360-degree performance appraisal for the department $\mathrm{f}$

Figure 6 indicates that unlike others, the Head of Department F received the highest score by his/her superior. Despite the small difference, the lowest score given to him/her was given by his/her subordinates. The highest score of the Head of Department F among all the 4 dimensions was given on the dimension of "Approachability and Communication", similar to the others.

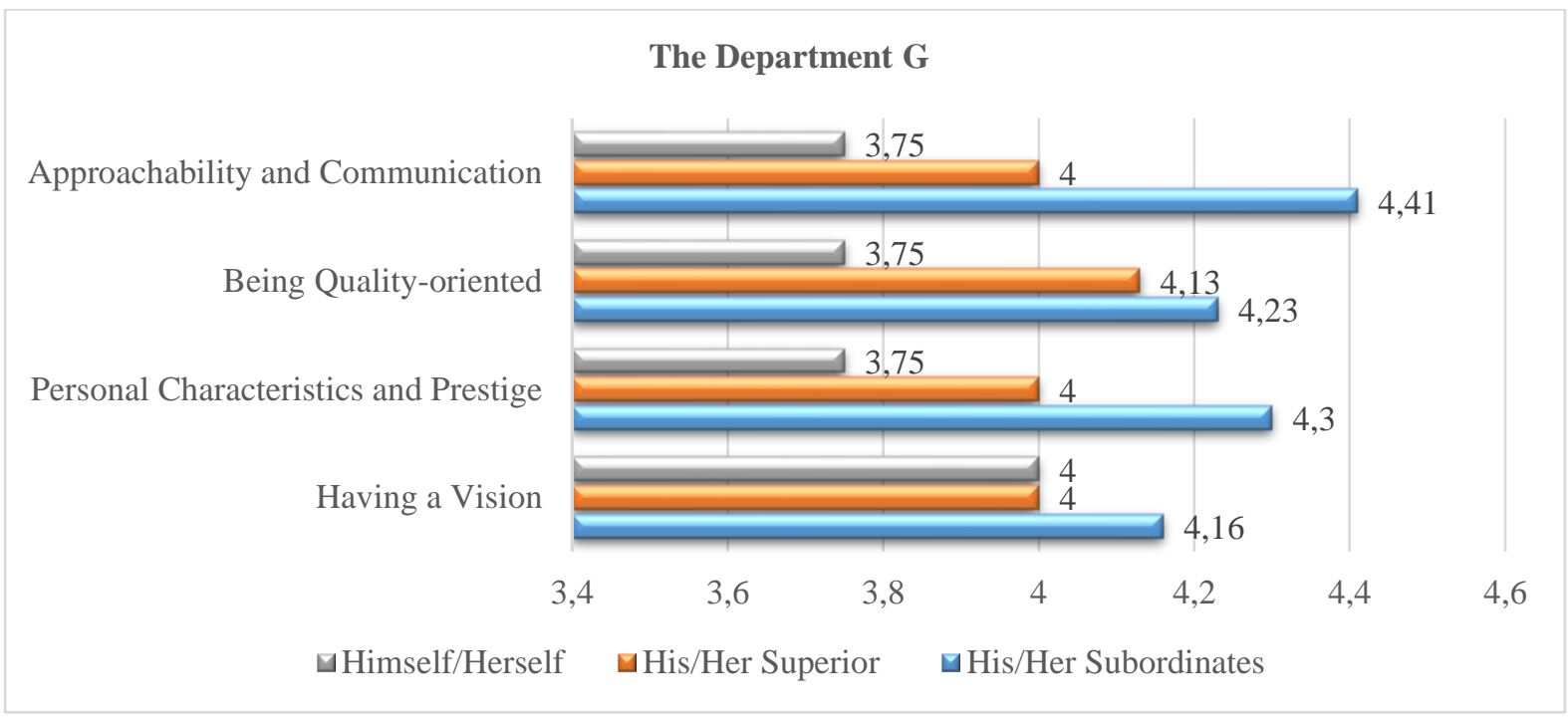

Figure 7: 360-degree performance appraisal for the department $g$

Figure 7 demonstrates that while the highest score of the Head of Department G was given by his/her subordinates, he/she received the lowest score from himself/herself, unlike the others. The highest score of the Head of Department $\mathrm{G}$ among all the 4 dimensions was given on the dimension of "Having a Vision" and "Approachability and Communication."

\section{Conclusion}

Today, when performance evaluations are of critical importance, various performance evaluation systems are being established to allow organizations to carry out an evaluation in line with their goals. One of these systems is 360-degree performance appraisal and feedback system. When accurately conducted, this system overcomes the shortcomings of traditional 
evaluation methods, enables the employees in an organization to be self-confident, and enhances productivity.

It'seen that investigations in different areas were conducted by using the 360-degree performance appraisal system and also meanwhile the effects of this system were measured in some investigations. Murat and Bağrıaçık (2011), measured the performances of second class presidents in Zonguldak Karaelmas University, which belong last one year duration by using this system and found out significant distinctions among participants. Camgöz and Alperten (2006), applied this system in order to evaluate directorial competences of a university medicosocial center unit presidents, found out that some unit presidents tend to evaluate their own performance with higher score. Gümüştekin et all. (2010), conducted an investigation devoted to be defined the effects of 360-degree performance appraisal system on organizational commitment and underlined the positive effects of this system on organizational commitment. Arslan et all. (2016), investigated the influence of this appraisal system on organizational justice perception in an management and came a conclusion that employees perceive this system as fair. It's also introduced with these investigations that objective findings about performances will be reached, employees' loyalty to institutions will increase, corporate justice will be established easier with applying the 360-degree performance appraisal system successfully.

In this regard, the present study evaluates the heads of departments at Çanakkale Onsekiz Mart University based on the 360-degree performance appraisal system. The survey in the study was administered to the subordinates in the departments at Çanakkale Onsekiz Mart University, to every head of department, to the superiors of the heads of departments, and to those who benefit from the services in some departments. A total of 145 people, with varying different positions and seniorities, participated in the survey and the section of the findings reveals the results of the survey.

In the light of the findings, in general, the highest score given to the heads of departments was given on the dimension of "Approachability and Communication." The heads of departments received their lowest scores from their superiors. Notably, some of them received their highest scores from themselves. It is evident that while these heads of departments found themselves competent and even successful in their positions, other appraisers believed that these heads of departments exhibit lower performance. The remarkable finding that some of them received their highest scores from themselves, indicates the significance of the 360-degree performance appraisal, from a theoretical point of view. Since this appraisal system enables appraisees to see their performance from the perspective of others, which also allows them to compensate for the weaknesses that go unnoticed by them.

In conclusion, this study pointed out that the data collected from multiple sources on the performance of the heads of departments through the 360-degree performance appraisal differed from each other, and identified their weaknesses and strengths. These findings provide important insights on the performance of the heads of departments and are instrumental for the organization to determine its educational policies to reach its achievement goals.

\section{References}

Akdoğan, A. \& Demirtaş, Ö. (2009). 360 derece performans değerlendirme sistemi: askeri imalat işletmesinde yöneticiler üzerinde bir uygulama. Atatürk üniversitesi iktisadi ve idari bilimler fakültesi dergisi, 23(1), 49-71.

Alexandrua, M. \& Diana, M. (2015). Management skills assessment using $360^{\circ}$ feedback - MSF 360. Procedia - Social and Behavioral Sciences, 187, 318-323.

Arslan, A. E. \& Baş, M. \& Özler, D. E. (2016). 360 Derece performans değerlendirmenin bir işletmedeki örgütsel adalet algısı üzerine etkisi. Sosyal bilimler dergisi, 49, 78-95. 
Bağrıçık, İ. (2009). Kamuda 360 derece performans değerlendirme: örnek bir uygulama. (Basılmamış Yüksek Lisans Tezi), Zonguldak Karaelmas Üniversitesi, Zonguldak.

Barutçugil, İ. (2002). Performans yönetimi. İstanbul: Kariyer yayıncılık.

Brett, J. F. \& Atwater, L. E. (2001). $360^{\circ}$ feedback: accuracy, reactions, and perceptions of usefulness. Journal of applied psychology, 86(5), 930-942

Camgöz, S. M. \& Alperten, N. (2006). 360 derece performans değerlendirme ve geri bildirim: bir üniversite mediko-sosyal merkezi birim amirlerinin yönetsel yetkinliklerinin değerlendirilmesi üzerine pilot uygulama örneği. Yönetim ve ekonomi dergisi, 13(2), 191-212.

Cheung, G. S. Y. (1999). Introducing a 360 degrees performance evaluation. Strategic Change strat. Change, $8,111-117$.

Dinç, E. (2005). 360 derece performans değerleme sistemi ve bir uygulama. (Basılmamış yüksek lisans tezi), Uludağ üniversitesi, Bursa.

Durmuş, B. \& Çinko, M. \& Yurtkoru, E. S. (2016). Sosyal bilimlerde SPSS'le veri analizi. İstanbul: Beta yayınları.

Garavan, T. N. \& Morley, M. \& Flynn, M. (1997). 360 Degree feedback: its role in employed development. Journal of management development, 16(8), 134-147.

Gillen, T. (1997). Değerlendirme tartışması. (B. Aksu \& O. Cankoçak, Çev.) Ankara: İlk kaynak kültür ve sanat ürünleri.

Göksel, A. (2013). Işsletmelerde performans değerlendirme sistem tasarımı. Ankara: Nobel akademik yayıncilik.

Gümüştekin, G. E. \& Özler, D. E. \& Y1lmaz, F. (2010). 360 derece performans değerleme sisteminin örgütsel bağlılık üzerindeki etkisinin belirlenmesine yönelik bir araştırma. Business and Economics Research Journal, 1(1), 1-20.

Güngör, F. \& Biberci, M. A. (2011). 360 derece performans değerlendirme yönteminin AHP analizi ile karşılaştırılması ve bir uygulama. Üretim araştırmaları sempozyumu, İstanbul Ticaret üniversitesi, 371-381.

Haigh, C. H. (2016). The 360 performance evalution tool. http://www.fireengineering.com/articles/print/volume-169/issue-7/features/the-360performance-evaluation-tool.html, Erişim Tarihi: 03.06.2017.

Kara, D. (2010). Performans değerlendirme yöntemi olarak 360 derece geribildirim sürecinin orta kademe yöneticilerin iş başarısına olan etkisi: 5 yıldızlı otel işletmelerinde bir uygulama. Doğuş üniversitesi dergisi, 11(1), 87-97.

Karkoulian, S. \& Assaker, G. \& Hallak, R. (2016). An empirical study of 360-degree feedback, organizational justice, and firm sustainability. Journal of business research, 69, 18621867.

Kaymaz, K. (2007). Davranış boyutuyla performans geribildirim olgusu ve süreci. Ankara üniversitesi SBF dergisi, 62(4), 141-178.

Kubat, G. (2012). Öz değerlendirmenin 360 derece performans yönetimi uygulama modeli geri besleme yöntemindeki işlevselliği. Hitit üniversitesi sosyal bilimler enstitüsü dergisi, 1 , 51-65.

Levine, M. (2010). Taking the burn out of the 360 degree hot seat. Training and development, 64(8), 40-45.

Mabey, C. (2001). Closing the circle: participant views of a 360 degree feedback programme. Human resource management journal, 11(1), 41-53.

Murat, G. \& Bağrıaçık, İ. (2011). Kamuda 360 derece performans değerlendirme: Zonguldak Karaelmas Üniversitesi örneği. Süleyman Demirel Üniversitesi İktisadi ve İdari Bilimler Fakültesi Dergisi, 16(1), 1-24. 
Oruç, K. E. \& Armaneri, Ö. \& Yalçınkaya, Ö. (2008). 360 derece performans değerleme ve web tabanlı bir model ile kurumsal verimliliğin arttırılması. Endüstri mühendisliği dergisi, 19(1), 4-18.

Palmer, M. (1993). Performans değerlendirmeleri. (D. Şahiner, Çev.), İstanbul: Rota Yayınevi.

Pocket Mentor, (2009). Performans değerlendirmesi. (M. İnan, Çev.), İstanbul: Optimist yayınevi.

Rodgers, K. G. \& Manifold, C. (2002). 360-degree feedback: possibilities for assessment of the ACGME core competencies for emergency medicine residents. Acad Emerg Med., 9(11), 1300-1304.

United States Office of Personnel Managemen (1997). Performance management practitioner series. 360-degree assessment: an overview, https://www.opm.gov/policy-dataoversight/performance-management/performance-managementcycle/rating/360assessment.pdf, Erişim tarihi: 04.06.2017.

Uygur, A. \& Sarıül, S. S. (2015). 360 derece performans değerlendirme ve geri bildirim sistemi. Selçuk üniversitesi sosyal bilimler enstitüsü dergisi, 33, 189-201. 